\title{
Legal Pluralism as a Method of Interpretation: A Methodological Approach to Decolonising Indigenous Peoples' Land Rights under International Law
}

\section{Pluralismo legal como método de interpretación: un planteamiento metodológico para descolonizar los derechos de los pueblos indígenas a sus tierras en el marco del derecho internacional}

\author{
Jonas Perrin ${ }^{1}$ \\ jonas.perrin.ec@gmail.com
}

\begin{abstract}
Ever since the arrival of the European colonisers, theories of international law have been used to justify the process of dispossession of indigenous lands. Even though the adoption of human rights have led to some amelioration, the author claims that this has proved unsatisfactory to address indigenous concerns for one reason: international law remains deeply rooted in colonial concepts, such as the concepts of 'sovereignty' and 'property'. Given that these concepts clearly contradict indigenous cosmovisions, the author proposes a pluralist interpretation of indigenous land rights under international law. Understood as a method of interpretation, it is able to take into account not only 'state law' but also indigenous conceptions of the relationship between human beings and the land. It is thus proposed that such a methodological approach may decolonise colonial concepts of international law.
\end{abstract}

Keywords

Indigenous peoples' land rights, international law, legal pluralism, liberalism, indigenous cosmovision.

Forma sugerida de citar: Perrin, Jonas (2017). Legal Pluralism as a Method of Interpretation: A Methodological Approach to Decolonising Indigenous Peoples' Land Rights under International Law. Universitas, $X V(26)$, pp. 23-60.

1 Master of European and International Law (MLaw), University of Bern, Switzerland and Stockholm, Sweden. PhD student at the University of Lucerne, Switzerland, visiting Researcher at the Universidad Central del Ecuador, Quito, Ecuador. Academic research: public international law, human rights, indigenous rights, public law, constitutional law of Switzerland and Ecuador. 


\section{Resumen}

Desde la llegada de los colonizadores europeos, las teorías del derecho internacional han sido utilizadas para justificar el proceso de desposesión de las tierras indígenas. Aunque la adopción de derechos humanos ha conducido a una cierta mejora, el autor afirma que esto ha resultado insatisfactoriamente para abordar preocupaciones indígenas por una razón: el derecho internacional permanece profundamente arraigado en conceptos coloniales, tales como los conceptos de la "soberanía" y de la "propiedad". Dado que estos conceptos se contradicen claramente con la cosmovisión indígena, el autor propone una interpretación pluralista de los derechos indígenas a sus tierras en el marco del derecho internacional. Como método de interpretación, tal planteamiento pluralista es capaz de no solo tomar en cuenta la "ley estatal," sino también concepciones indígenas con respecto a la relación entre el ser humano y la tierra. Por lo tanto, el autor propone que tal planteamiento metodológico pueda descolonizar conceptos coloniales del derecho internacional.

\section{Palabras clave}

Derechos de los pueblos indígenas a sus tierras, derecho internacional, pluralismo legal, cosmovisión indígena.

\section{Introduction}

Since the first encounter between indigenous peoples and the European colonisers, indigenous peoples' history has been coined by dispossession of their lands and resources. In this process that continues to nowadays, international law has played a major role. In particular, the Western concepts of 'sovereignty' and 'property' have served as legal instruments for the justification of this process. With the advent of universal human rights in the aftermath of World War II, international law is presumed to have shifted away from this colonial approach. However, international law, including the concept of universal human rights, remains a product of Western philosophy and legal thought. This liberal worldview may collide with or even contradict indigenous cosmovisions, wherefore the current doctrine of international law and human rights appears dissatisfactory. In order to decolonise indigenous land rights under international law, I propose a pluralist interpre- 
tation of international law. This approach attempts to take into account the insights of legal pluralists in order to formulate a method of interpretation.

\section{The Colonial Legacy of International Law: 'Sovereignty' and 'Property' as Legal Instruments for the Denial of Indigenous Rights}

In 1492, when Christopher Columbus arrived to the 'new world', this first encounter raised the question as to how the peoples in those 'newly discovered' territories were to be dealt with. In this first period of colonisation, papal bulls served as quasi-legal bases for the justification of the dispossession of indigenous peoples' lands. In 1493 pope Alexander VI gave his blessing to the Spanish Crown for the annexation of all those territories of the 'new world' which had not yet been governed by a Christian ruler:

[W]e (...) assign to you and your heirs and successors, kings of Castile and Leon, (...) all islands and mainlands found and to be found, discovered and to be discovered towards the west and south (...) with this proviso however that none of the islands and mainlands, found and to be found, discovered and to be discovered, beyond that said line towards the west and south, be in the actual possession of any Christian king or prince (Pope Alexander VI, Inter Caetera, 4. Mai 1493, in Davenport 1917, p. 77).

Accordingly, the so-called doctrine of discovery justified the acquisition of lands wherever it had not yet been acquired by a Christian ruler (Doyle, 2015 , p. 21). However, this doctrine of discovery was not undisputed; it received criticism from the early naturalist theorists. In particular, they put forward that the mere 'discovery' did not suffice to constitute proper land titles. By reference to the theory of just war, it was rather argued that the acquisition of territories required a 'just cause' in order to create full entitlements (Davidson, 1994, p. 407). Francisco de Vitoria (1486-1547) argued that indigenous peoples bore certain duties towards the colonial masters such as the duty to tolerate the free trade amongst the colonisers, the duty not to interfere with the propagation of the Christian belief, and the duty to share the wealth of the lands with the colonial masters. However, a breach of those duties was considered a just cause, which gave the coloniser the right to forcibly acquire their lands, granting them territorial title over it 
(Vitoria, 1532/1917: III. 3; III. 9, III. 4). Against this background, the subsequent establishment of the encomienda and repartimiento system, which assigned lands to the conquistadores and obliged them to grant 'protection' and convert the indigenous to the Christian belief led to a de facto enslavement and dispossession of indigenous peoples and their ancestral territories (Gilbert, 2006, p. 6).

After the Peace of Westphalia and the resulting peace-treaties in 1648, a new era of international law and of the rights of indigenous peoples emerged. Whereas the early naturalist framework assumed that natural law encompassed all levels of human interaction and that those rights were accorded to all humans and all human entities and associations, the theories of the modern nation-state developed the hereinafter called 'individual/state dichotomy', leaving indigenous peoples outside the scope of application of international law (Anaya, 2004, p. 20). This dichotomy was based on the idea that natural law was a twofold conception, distinguishing between natural rights of individuals, and natural rights of nation-states. With his theory of social contract, Thomas Hobbes (1588-1679) provided the intellectual basis for such a dichotomy of natural law: In Leviathan, he argued that the state of nature was one of a 'war of all against all' (bellum omnium contra omnes) (Hobbes, 1691: 1. XIII), wherefore people would leave the state of nature by associating through a social contract in order to enter civil society. The state, representing civil society, pursued the goal of granting legal and physical safety by strong undivided government (Hobbes, 1691: 1. XIII; 2. XVII). According to Hobbes, the state was, analogously to the individual, bearer of natural rights (Hobbes, 1691: 2. XXX). In this sense, Hobbes created a natural rights dichotomy which granted a set of natural rights to individuals, and a different set of natural rights to states, whereas sovereignty became the right of states, property the right of individuals. However, the ultimate paradigm shift of international law was introduced by Emer de Vattel (1714-1767). He created a legal order, which exclusively recognised nation-states as subjects of international law. Thus international law was exclusively applicable between nation-states, leaving all individuals and entities not qualifying as nation-states beyond the scope of application of international law. Individuals could therefore base their claims only on domestic, but not on an international law (Anaya, 2004, p. 22). Furthermore, Vattel introduced his concept of territorial sovereignty described as follows: 
When a Nation takes possession of a country to which no prior owner can lay claim, it is considered as acquiring the empire or sovereignty over it, at the same time with the domain. For since the nation is free and independent, it can have no intention, in settling in a country, to leave to others the command of it, or any other rights that constitute sovereignty (Vattel, 1758/1844: I.XVIII, § 205).

Vattel's theory of territorial sovereignty raised the question whether indigenous peoples qualified as 'Nation' ${ }^{2}$ or as a different entity living in a territory with 'no prior owner'. If indigenous peoples qualified as a nation, they would have acquired sovereignty. If they were not considered a nation, they would not have owned the land wherefore the territory remained open to European acquisition. Vattel himself defined the term 'Nation' rather broadly as "political bodies, or a society of men united together for the purpose of promoting their mutual safety and advantage by their combined strength' (Vattel, 1758/1844: I.I., §1). According to his definition he argued that some indigenous peoples may constitute 'Nations', some not: '[T]he conquest of the civilized empires of Peru and Mexico was a notorious usurpation, the establishment of many colonies on the continent of North America might (...) be extremely lawful. The people of those extensive tracts rather ranged through than inhabited them' (Vattel, 1758/1844: I.VII., §82). The reason for this distinction lies in the modalities of the cultivation of the soil. While he admitted that sedentary societies could, in principle, constitute a 'Nation', he a priori rejected it for societies cultivating their land according to a non-European model:

The whole earth is destined to feed its inhabitants; but this it would be incapable of doing, it if were uncultivated. Every Nation is then obliged by law of nature to cultivate the land that has fallen to its share (...). [Indigenous peoples'] unsettled habitation in those immense regions cannot be accounted a true and legal possession; and the people of Europe, (...) were lawfully entitled to take possession of it, and settle it with colonies (Vattel, 1758/1844: I.VII, §81; I.XVIII, §209).

Thus, it resulted that whatever society did not meet the 'standard' of Vattels Eurocentric view of cultivation, was deprived of territorial sovereign-

2 Nation' and state' is used interchangeably. 
ty. The idea of superiority of European agriculture, hereinafter called 'agricultural argument' (Flanagan, 1989), did not only deny sovereign rights to many indigenous peoples, it was also used to deprive indigenous peoples of individual land rights. In particular, John Locke's (1632-1704) labour theory of property justified the idea of superiority of European agriculture. According to Locke 'every Man has a Property in his own Person. (...) The Labour of his Body and the Work of his Hands, we may say, are properly his' (Locke, 1689/2012: V. 27). From there on he concluded:

Whatsoever then he removes out of the State that Nature hath provided, and left it in, he hath mixed his Labour with, and joined to it something that is his own, and thereby makes it his Property. In being by him removed from the common state Nature placed it in, it hath by his labour something annexed to it, that excludes the common right of other Men. For this Labour being the unquestionable Property of the Labourer, no Man but he can have a right to what that is once joined to, at least where is enough, and as good left in common for others (Locke, 1689/2012: V. 27).

Accordingly, whoever mixed his labour with an item in the state of nature became the proprietary of it. With a view to indigenous societies organized as hunters and gatherers he admitted that the hunter became proprietary of the hunted wild game and the gatherer of the gathered fruits: 'The fruit, or venison, which nourishes the wild Indian, (...), must be his (...). [T] his law of reason makes the deer that Indian's who hath killed it; it is allowed to be his goods, who hath bestowed his labour upon it' (Locke, 1689/2012: V. 26). On the other hand, killing the deer and gathering the fruit did not, according to Locke, suffice to establish land property rights. Non-sedentary indigenous peoples were thus deprived of land property rights, rendering the concerned territories vacant territories (Gilbert, 2006, p. 24).

In the $19^{\text {th }}$ and early $20^{\text {th }}$ century, when the Americas had already been 'decolonised', legal theory justifying colonisation in large parts of Africa and Asia shifted away from natural law theories towards a purely positivist approach of international law. Due to the Enlightenment and the emerging scientific disciplines, international law experienced somewhat a 'scientification': Whereas law had been dominated for a long time by religious and natural law considerations, it now became strongly influenced by contemporary anthropologists, sociologists, cultural historians and legal scholars (Thornberry, 2002, p. 72). With its scientification, social Darwinian theories 
of superiority and inferiority came into play (Doyle, 2015, p. 48). According to the positivist theories, whether or not an entity could qualify as a nationstate strongly depended upon whether the entity in question could meet the test of 'civilisation' (Westlake, 1894, p. 141). As to what criteria needed to be met in order to qualify as either 'civilised' or 'uncivilised', John Westlake (1828-1913) argued with the criterion of 'sufficient government':

When people of the European race come into contact with American or African tribes, the prime necessity is a government under the protection of which the former may carry on the complex life to which they have been accustomed in their homes, which may prevent that life from being disturbed by contests between different European powers for supremacy on the same soil, and which may protect the natives in the enjoyment of a security and well being at least not less than they enjoyed before the arrival of the strangers. Can the natives furnish such a government, or can it be looked for from the Europeans alone? In the answer to that question lies, for international law, the difference between civilisation and want of it (...). The inflow of the white race cannot be stopped where there is land to cultivate, ore to be mined, commerce to be developed, sport to enjoy, curiosity to be satisfied. If any fanatical admirer of savage life argued that the whites ought to be kept out, he would only be driven to the same conclusion by another route, for a government on the spot would be necessary to keep them out. Accordingly international law hast to treat such natives as uncivilised (Westlake, 1894, p. 141).

Besides the racist distinction between 'civilised' and 'uncivilised' peoples, the theory of recognition played a major role in the dispossession of indigenous lands and the denial of their sovereignty. According to the theory of recognition, an entity could only become a member to the 'Family of Nations' through the recognition by the already existing nation-states. Thus, the status of an entity depended upon admittance by the 'Family of Nations'. Concerning the theory of recognition, Lassa Oppenheim (1858-1919) stated:

Whenever a multitude of individuals living on or entering into such a part of the surface of the globe as does not belong to the territory of any member of the Family of Nations, constitute themselves as a State and nation on that part of the globe, a new State comes into existence. This State is not, by reason of its birth, a member of the Family of Nations. (...) It is through recognition, which is a matter of law, that such a new State becomes a member of the Family of Nations and a subject of International Law. As soon as recognition 
is given, the new State's territory is recognised as the territory of a subject of International Law, and it matters not how this territory was acquired before the recognition (Oppenheim, 1905: § 209 (1)).

As recognised nation-states were the only subjects of international law, and thus the only entities vested with the power to derive rights from rules that had been created for their own purposes, indigenous peoples were once again left beyond the scope of application of international law. Furthermore, occupation constituted a legitimate means of acquisition of sovereignty (Oppenheim, 1905: $§ 211)$, wherefore indigenous territories were treated as terra nullius (Anaya, 2004, p. 29). Accordingly, regulation of private property fell under the exclusive domain of the nation-state, thus leaving indigenous peoples' property rights to the discretion of national legislation (Oppenheim, 1905: $§ 228$ ).

In the Americas, the successor states of the colonial powers achieved their independence mostly by war. After the achievement of independence from the former British colonies in North America, lawsuits concerning indigenous territories were brought before domestic courts. The 1823 case Johnson v. M'Intosh concerned a property dispute between Thomas Johnson and William M'Intosh. Johnson based his claim on the purchase of the lands in question from the Piankeshaw, whereas M'Intosh had received a land title from the government of the United States, which itself was based on the right of conquest issued by King Henry VII (Williams, 1990, p. 121; Williams, 1991, p. 70). Chief Justice John Marshall thus had to decide on whether the Piankeshaw had dominion over their lands, granting them the power to sell it to Johnson. Justice Marshall argued:

On the discovery of this immense continent, the great nations of Europe were eager to appropriate to themselves so much of it as they could respectively acquire. (...) The exclusion of all other Europeans necessarily gave to the nation making the discovery the sole right of acquiring the soil from the natives and establishing settlements upon it. It was a right with which no Europeans could interfere. It was a right which all asserted for themselves, and to the assertion of which by others all assented. In the establishment of these relations, the rights of the original inhabitants were in no instance entirely disregarded, but were necessarily to a considerable extent impaired. They were admitted to be the rightful occupants of the soil, with a legal as well as just claim to retain possession of it, and to use it according to their own discretion; but their rights to complete sovereignty as independent nations 
were necessarily diminished, and their power to dispose of the soil at their own will to whomsoever they pleased was denied by the original fundamental principle that discovery gave exclusive title to those who made it. Those relations which were to exist between the discoverer and the natives were to be regulated by themselves. The rights thus acquired being exclusive, no other power could interpose between them. (...) The history of America from its discovery to the present day proves, we think, the universal recognition of these principles. (...) [T] he tribes of Indians inhabiting this country were fierce savages whose occupation was war and whose subsistence was drawn chiefly from the forest. To leave them in possession of their country was to leave the country a wilderness (U.S., 1823: 573 f.; 590).

Chief Justice Marshall thus legitimised the doctrine of discovery, which vests the first European conqueror with ultimate sovereignty to the detriment of indigenous peoples who were left with a mere right of occupancy depending upon the will of the self-proclaimed sovereign. In 1831 Chief Justice Marshall had to decide in the case Cherokee Nation v. Georgia. The Cherokee nation sought an injunction against legislation passed by the state of Georgia justifying their forced relocation. Justice Marshall had to decide on whether the court had jurisdiction to decide the matter. According to the U.S. Constitution this was the case if the Cherokees were to be considered a 'foreign state' (U.S., 1831: 1). Justice Marshall first acknowledged that the Cherokees were a state: 'The Cherokees are a State. They have been uniformly treated as a State since the settlement of our country' (U.S., 1831: 1). Unsurprisingly however, he denied them the status of a foreign state in the meaning of the constitution and introduced the doctrine of 'domestic dependent nations':

It may well be doubted whether those tribes which reside within the acknowledged boundaries of the United States can, with strict accuracy, be denominated foreign nations. They may more correctly, perhaps, be denominated domestic dependent nations. They occupy a territory to which we assert a title independent of their will, which must take effect in point of possession when their right of possession ceases; meanwhile, they are in a state of pupillage. Their relations to the United States resemble that of a ward to his guardian (U.S., 1831, p. 30).

The contradiction between ascribing them the attributes of a state, but nevertheless denying them territorial sovereignty led to the absurdity that they "were sovereign enough to enter into treaties with the purpose of ceding 
legal title to their lands and territories, but they were not sovereign enough to continue to function as an independent political entity. Nor, for that matter, were they sovereign enough to protect the remnants of their sovereignty against incursion of the state' (Churchill and Morris, 1992, cited in SchulteTenkoff, 1998, p. 248). In sum, Chief Justice Marshall clearly argued that indigenous peoples' territories fell under the exclusive sovereignty of the nation-state in which their lands are located. In this sense they were subordinated to the structures of the newly emerged state.

From 1813 on the successful wars of independence against the Spanish Crown led to the nation building of most of the Latin American states. The demarcation of the newly independent nation states' borders was largely based on the principle of uti possidetis. This principle stems from the Roman ius civile and was originally used to settle disputes on private property among individuals. Notwithstanding its civil law origins, the creole elites reinterpreted the principle in order to justify the maintenance of the colonial borders (Reisman, 1995, p. 352; Ratner, 1996, p. 592 f.). Uti possidetis was now used as a principle of international law that determined permanent sovereignty over a certain territory (Moore, 1913, p. 8). Consequently, indigenous peoples living on their ancestral lands were automatically transferred from the former administrative units of the Crowns into the newly emerging successor states. For indigenous peoples, 'decolonisation' administered by the principle of uti possidetis meant nothing else than the continuance of colonisation under an exchanged regime. Therefore this process is sometimes referred to as 'internal colonisation' (Tully, 2007, p. 37). That uti possidetis has nowadays become a principle of international law concerning frontier disputes shows the El Salvador/Honduras Frontier Dispute Case. In 1992 the ICJ had to determine to which successor state certain lands, islands and the maritime space of the Gulf of Fonesca belonged. Concerning the disputed demarcation, El Salvador pointed to Art. 26 of the former peace treaty, which referred, in case of controversies, not only to the administrative borders of the Crown, but also to former indigenous peoples and their respective boundaries:

For the delimitation of the frontier line in areas subject to controversy, the Joint Frontier Commission shall take as a basis the documents which were issued by the Spanish Crown or by any other Spanish authority, whether secular or ecclesiastical, during the colonial period, and which indicate the jurisdictions or limits of territories or settlements (poblaciones). It shall also 
take account of other evidence and arguments of a legal, historical, human or any other kind, brought before it by the Parties and admitted under international law (ICJ, 1992: § 47).

Drawing attention to the term poblaciones, El Salvador was of the opinion that the Court had to determine the demarcation on the basis of these indigenous land titles: It thus asked the Court:

To determine the limits between the municipal territories of these Indian 'poblaciones' or settlements and not between ancient Spanish provinces or the limits of private land properties, is what has been agreed in Article 26, as the method to be applied in order to implement in this case the principle of uti possidetis juris. And this may be done only on the basis of the titulos ejidales $^{3}$ invoked by El Salvador ICJ, 1992: § 49).

Nonetheless, the Court did not contemplate these considerations and held that '[i]t was the administrative boundaries between Spanish colonial administrative units, not the boundaries between Indian settlements as such, that were transformed, by the operation of the uti possidetis juris, into international boundaries in 1821' (ICJ, 1992: $\$ 50$ ). Hence, the Court concluded that the principle of uti possidetis meant the perpetuation of the colonial borders only and that indigenous lands were not to be considered under international law. This unawareness of indigenous lands reflects the situation of indigenous peoples in international law as internally colonised people.

In domestic legislation many successor states implemented guardianship doctrines, based on the assumption that indigenous peoples were 'uncivilised' and thus inferior. For example, according to Art. 64 of the Argentinian constitution of 1853 , the congress was obliged to maintain peaceful relations with the 'Indios' and to promote their conversion to the Christian belief. ${ }^{4}$ Similarly, Art. 6 of the Brazilian civil code of 1916 read as follows: 'The savages shall remain subject to the tutelary regimen established by special laws and regulations which shall cease as they become adapted to the civilization of the country' (Conn, 1988, p. 269 ff.). Decree No. 5464 of 1928 additionally distinguished four categories of Indians, whose status and

3 Communal land titles.

4 Art. 64 Argentinian Constitution 1853: "Corresponde al Congreso: conservar el trato pacífico con los indios, y promover la conversión de ellos al catolicismo". 
rights, such as legal capacity and property rights, depended on the degree of their 'assimilation' (Conn, 1988, p. 269 ff.). Meanwhile in Canada, the federal government amended the 1876 Indian Act in 1927, which severely restricted access to justice for indigenous peoples (Chief Mathias and Yabsley, 1991, p. 35) and outlawed in an even more extensive fashion than its predecessor, the potlatch ${ }^{5}$ and sacred dancing, since it was considered excessive, wasteful and contrary to assimilation (Joseph, 2012; Chief Mathias and Yabsley, 1991, p. 37).

In conclusion, regarding the history of international law, three important points have to be made. Firstly, international law is a product of Western philosophy and legal thought. Secondly, through colonisation this Western product was exported to the whole world and unilaterally imposed upon indigenous peoples. Thirdly, international law theories were aimed at, and developed through, colonisation. Thus, the dispossession of indigenous lands and the denial of indigenous rights are inextricably connected to international law.

\section{The Era of Human Rights: Indigenous Cosmovision trapped in a Liberal World}

A purported paradigm shift away from the colonial character of international law came into being in the aftermath of World War II. The foundation of the United Nations led to the abolishment of the right to conquest, and to the enshrinement of the right to self-determination of peoples as a means for ending colonisation in the UN-Charter ${ }^{6}$. Additionally, with the adoption of the Universal Declaration of Human Rights (UDHR) in 1948, and the subsequent entry into force of the two main UN Human Rights Treaties $^{7}$, universal human rights became a cornerstone of international law. This development will subsequently be referred to as the 'era of rights' or the 'era of human rights'. With regard to decolonisation and self-determination however, the situation of indigenous peoples barely changed. With the introduction of the principle of territorial integrity the colonial borders became

5 Gift bearing tradition to celebrate the passing of names, titles and responsibilities, to distribute wealth, establish rank and celebrate weddings and births.

6 See Art. 2 (4) of the Charter of the United Nations of 1945.

7 International Covenant on Civil and Political Rights (ICCPR); International Covenant of Economic, Social and Cultural Rights (ICESCR). 
sacrosanct. Furthermore, the right to self-determination was, with reference to the so-called 'Blue Water Thesis' or 'Salt Water Thesis', not applied to indigenous peoples: At the UN General Assembly the assumption prevailed that the right to self-determination only applied to territories which are separated from their coloniser through the sea ${ }^{8}$. As a result, indigenous peoples living within the borders of a successor state were denied the right to self-determination.

In respect of the entry into force of universal human rights, it is often argued that the commencement of the 'era of rights' led to a paradigm shift of indigenous rights. ${ }^{9}$ However, bearing in mind that self-determination is closely linked to sovereignty and the human right to property, one has to be aware that both of these concepts are very deeply anchored in Western legal thought. With colonisation, both the concept of sovereignty and the human right to property were exported and unilaterally imposed, and with the foundation of the UN even universalised. Sovereignty, property, and human rights as such are thus frequently criticised by indigenous peoples and indigenous scholars, du to their Western origins (Paulson, 2016, p. 10; Martínez de Bringas, 2003, p. 41 ff.). In this context, Keal concludes, that 'the conjunction of discourses of property and sovereignty has been a vital element in the dispossession of indigenous peoples' (Keal, 2008, p. 324). The next subsection shall therefore focus on a comparison of the liberal worldview and the indigenous cosmovision with regard to property and sovereignty.

\section{'Property' and 'Sovereignty' in Indigenous Comsovision}

Although indigenous conceptions, cultures and convictions vary considerably among each other, it is always emphasised that there is a common denominator among indigenous peoples regarding the relationship to their ancestral territories (Stavenhagen, 2006, p. 26; Gilbert and Doyle, 2011, p. 289; Göcke, 2016, p. 15 ff.; Kuprecht, 2013, p. 46 ff.). This relationship di-

8 Declaration of Granting Independence to Colonial Countries and Peoples, adopted by the UN General Assembly Resolution 1514 (XV) of December 14 1960; Principles which should Guide Members in Determining Whether or not an Obligation exists to transmit the Information Called for under Article 73e of the Charter, adopted by UN General Assembly Resolution 1541 (XV) of December 161960.

9 See Section III, 2. 
ffers strongly from what will subsequently be referred to as the 'liberal' or 'Western' conviction of the conception of property and sovereignty. In Western philosophy, land, and nature in general, is conceived subordinate to the human being. Therefore, it has been treated as a commodity or good, over which the human being may dispose. Aristotle for example argued that the 'special capacity' of the human soul was unique and very different from nature as such. Due to man's special capacity he created a hierarchical relationship between human beings and nature, subordinating the latter to the use and enjoyment of the first (Aristotle, 2014: I. 6 cited in Cortez and Wagner, 2010, p. 171). The idea of nature being subject to the human being is regularly referred to as an 'ontological break' with nature (Cortez, 2011, p. 2; Houtart, 2011, p. 62; Torres Santana, 2012, p. 183). This ontological break can already be identified and traced back to the biblical texts. In Genesis, God instructs Noah and his sons:

Be fruitful and increase in number and fill the earth. The fear and dread of you will fall on all the beasts of the earth, and on all the birds in the sky, on every creature that moves along the ground, and on all the fish in the sea; they are given into your hands. Everything that lives and moves about will be food for you. Just as I gave you the green plants, I now give you everything (Genesis 9, 1-3).

In the same vein, St. Thomas Aquinas clearly referred to the idea of human superiority in his Summa Theologiae, where he stated that the 'natural dominion of man over other creatures, which is competent to man in respect of his reason wherein God's image resides, is shown forth in man's creation' (St. Thomas Aquinas, 1265-1274/1989: II, II, Q. 66). This exclusively anthropocentric stance has, until today, strongly influenced liberal thought. Even modern theories of justice are coined by an anthropocentric view. For instance, Amartya Sen's and Martha C.Nussbaum's capability approach refer to Aristotle's practical philosophy of the 'good life'. Even though Nussbaum stresses the importance of a deep bond with animals, plants, and nature, she follows anthropocentrism in the sense that nature remains a means to the end of the good life of, and is thus subordinated to, human beings (Schmid, 2014, p. 84). In this sense, Nature remains a mere object, rather than subject, with the purpose of serving and satisfying human needs.

In contrast to this anthropocentric view of liberal theory, indigenous peoples conceive nature as a holistic concept (Cortez, 2010, p. 232). For 
indigenous peoples in the Amazon region and the Andes, this is expressed through the concept of Sumak Kawsay (Kichwa) or Suma Qamaña (Aymara), which, roughly translated means a 'life in plenitude' (Altmann, 2016, p. 58; Villalba, 2013, p. 1430). Sumak Kawsay and Suma Qamaña as principles were introduced in both the Ecuadorian and the Bolivian constitutions in 2008 and 2009 (Altmann, 2016, p. 56; Hidalgo-Capitán and Cubillo-Guevara, 2013, p. 26). However, the exact meaning of Sumak Kawsay remains unclear. In this context, Hidalgo-Capitán and Cubillo-Guevara describe three different interpretational currents of it: a socialist, state-centred interpretation, an ecologist and post-development interpretation and an indigenous and "pachamamist" interpretation (Hidalgo-Capitán and Cubillo-Guevara: 2013, p. 27 with reference to Hidalgo-Capitán, 2012). Since this article attempts to elaborate indigenous peoples' claims, the subsequent discussion focuses on the indigenous interpretation of Sumak Kawsay. In this sense, the concept is based on the idea that man does not have the right to dominate and dispose over nature. Rather the relationship between man and nature is characterised by values such as solidarity, reciprocity, and complementarity. It is thus a relationship of subject to subject, as opposed to a subjectobject-relation in liberalism (Schmid, 2013, p. 9). Against this background, Sumak Kawsay means to live in harmony and balance; in harmony with the cycles of Mother Earth, the cosmos, and in balance with any form of existence (Huanacuni, 2010a, p. 46). It thus stands not only for a biocentric, but rather a cosmocentric worldview (Villalba, 2013, p. 1431). This cosmocentrism therefore stands in stark contrast to the Western notions of property and sovereignty, since the underlying idea of these notions are inextricably connected to power of control over and disposal of nature, and thus territory, by man.

Regarding the notion of property, according to liberalism, it is commonly defined as individual, and private property and nowadays constitutes one of the main pillars of Western economy and philosophy. This individualistic stance in liberal theory is not only applied to property as such. It clearly reflects the predominant view that the individual is considered the most important moral unit in liberalism. For instance, in a Theory of Justice, John Rawls' two principles of justice ascertain this individualist approach inasmuch as he calls for the same equal rights to basic liberty for "each person' (Rawls, 1971, pp. 53; 60). Secondly, property is private. Whereas Plato was rather reluctant to the institution of private property (Pipes, 1999, p. 6), 
already Aristotle advocated private property on several grounds. For example, he claimed that common property is taken the 'least care' of (Aristotle, 2004, p. 1261a) and put forward that 'what is one's own' makes human beings 'cherish and feel affection' (Aristotle, 2004, p. 1261b). At the latest with Locke's view on property, liberalism became unimaginable without the institution of private property. For example, libertarian theorist Robert Nozick, referring to Locke, considers private property even a natural right (Nozick, 1974, p. 25; Koller, 1981, p. 141). In indigenous cosmovisions, however, these arguments are untenable. With a view to individualism, Unai Villalba states: 'The community is conceived of as a unit of life made up of all forms of existence; not just a social structure made up of humans only. Community does not imply a lack of individuality, since individuality is expressed through complementarity with other beings in the group' (Villalba, 2013, p. 1430). Fernando Huanacuni argues that for many indigenous peoples of Abya Yala ${ }^{10}$, culture and life is necessarily communitarian, because everything is united and integrated, in the sense of interdependence between everything and everyone (Huanacuni, 2010b, p. 18). Thus the practical embodiment of such a cosmovision is based on collective property on means of production, wherefore private property cannot exist (Macas, 2010, p. 452). In sum, the concept of property in a Western sense is rejected by many indigenous peoples since the notion of individual and private property contradict, and has no base in, indigenous cosmovisions.

The notion of sovereignty, understood as state or territorial sovereignty, is regularly traced back to the Roman jurist Ulpian, who argued that the Emperor had absorbed the original imperium populi Romani and was thus not bound by the law but nevertheless vested with the power to legislate (Hinsley, 1966, p. 42). After Reformation, Jean Bodin (1530-1596) argued for absolute and perpetual sovereignty (Bodin, 1576/1606: I. VIII). In contemporary international law, the notion of sovereignty is commonly divided into internal and external sovereignty. It is argued that external sovereignty means that every nation-state is subject to international law only, but not to other nation-states and their domestic legislation. As a consequence, the principles of equality among states, the prohibition of intervention, and the respect for territorial integrity became vital elements of sovereignty (Shaw,

10 Abya Yala stands for the Kuna name of the American continent. Nowadays the term is more broadly used in the context of indigenous peoples of Latin America. 
2014, p. 153 ff.; Cassese, 2005, p. 46 ff.; Peters, 2016, p. 30). In this sense, sovereignty logically presupposes the existence of a nation-state. Both the concept of a Western nation-state and its attribute of sovereignty are often rejected by indigenous peoples and indigenous scholars. With regard to sovereignty, Dale Turner, an indigenous scholar, clearly rejects the concept of sovereignty since it has been 'the most devastating landscapes that have been forced upon Aboriginal peoples. (...) These intellectual traditions have created discourses on property, ethics, political sovereignty, and justice that have subjugated, distorted, and marginalized Aboriginal ways of thinking' (Turner, 2001, p. 325). In this context, Menno Boldt and Tony Long argue:

By adopting the European-Western ideology of sovereignty, the current generation of Indian leaders is buttressing the imposed alien authority structures within its communities, and is legitimizing the associated hierarchy comprised of indigenous political and bureaucratic elites. This endorsement of hierarchical authority and a ruling entity constitutes a complete rupture with traditional indigenous principles (Alfred, 2009, p. 80).

Similarly, Taiaiake Alfred, a Kahnawake (Mohawk) scholar, notes that sovereignty 'cannot be seen as an appropriate goal or framework [for indigenous peoples], because it has no relevance to indigenous values' (Alfred, 2009, p. 78). Keal, referring to Alfred, points to the differing understandings of power. He observes that whereas power in the Western sense derives from the alienation and domination of nature, and thus the treatment of land as private property, indigenous peoples see themselves more as stewards of the land, bearing responsibilities for its care and preservation without commodifying it (Keal, 2008, p. 323). As regards the very concept of the nationstate, it has always been emphasised that this concept is foreign, unwanted and thus rejected by many indigenous peoples and indigenous scholars. Alfred argues:

Traditional indigenous nationhood stands in sharp contrast to the dominant understanding of 'the state': There is no absolute authority, no coercive enforcement of decisions, no hierarchy, an no separate ruling entity. In accepting the idea that progress is attainable within the framework of the state, therefore, indigenous people are moving toward acceptance of forms of government that more closely resemble the state than traditional systems (Alfred, 2009, p. 80). 
Especially in connection with self-determination of indigenous peoples, many governments seem to ignore the fact, that most indigenous people do not aspire nation-building in a Western sense. Therefore, the apprehension of many governments that the right to self-determination may disrupt their borders and infringe on their territorial integrity appears unfounded (Gilbert, 2006, p. 220.). Against this background, James Anaya stated: '[T]he notion, that self-determination necessarily means a right to choose independent statehood, ultimately rests on a narrow state-centred vision of humanity and the world' (Anaya, 2002, p. 11). In the same vein, Lars-Anders Baer argues that 'the aim of our advocacy (...) has nothing to do with the creation of western style nation-states' (Baer, 2000, p. 230). In sum, it can be held that many indigenous peoples and scholars reject both the concept of property and of sovereignty since these concepts are based on an anthropocentric and individualistic stance, wherefore they contradict their own values and aspirations.

\section{Universal Human Rights: A Liberal Cure for Indigenous Peoples?}

As mentioned above, with the establishment of the United Nations and the adoption of various universal human rights treaties, international law is supposed to have taken a step back from its colonial character. With a view to the situation of indigenous peoples, legal scholars generally argue that the 'era of rights' has commenced. Gilbert states that '[r]ecent developments in international human rights law have arguably signalled the end of the age of dispossession' (Gilbert, 2006, p. 85). Even more assuming the language of indigenous rights, Thornberry's Chapter dedicated to the post-1945 era is titled 'The age of rights' (Thornberry, 2002, p. 89). However, two points have to be made. Firstly, while it is true that, due to the adoption of human rights, such as the right to property and the right to self-determination of all peoples ${ }^{11}$, state sovereignty has lost some of its traditional significance in the contemporary legal system of international law, it is still founded on the Westphalian concept, in which nation-states are the only fully-fledged subject of international law (Anaya, 2009, p. 50). Hence, for example, UN membership

11 Art. 1 ICCPR; Art. 1 ICESCR; Art. 3 UNDRIP. 
and the complaints procedures before the International Court of Justice (ICJ) are limited to states. Secondly, although human rights have been accepted with the foundation of the UN, the situation of indigenous peoples had not been on its agenda for a very long time. First and foremost, it was indigenous protests and uprisings in the 1960ies and 1970ies, e.g. the protest march Trail of Broken Treaties in 1971 in the United States, which led to increased attention of indigenous issues within the UN system and in the human rights debate in general (Corntassel and Primeau Hopkins, 1995, p. 343; Wilmer, 1993, pp. $18 \mathrm{ff} ; 136 \mathrm{ff}$.). Nevertheless, the individual complaints procedures of various human rights courts and treaty bodies have to deal with an increasing number of complaints filed by indigenous representatives. Especially in Latin America, the Inter American Court of Human Rights (IACtHR) decided some major cases in favour of indigenous peoples (IACtHR, 2001; IACtHR, 2006a; IACtHR, 2006b; IACtHR 2007; IACtHR, 2012).

While it is true that indigenous peoples profited at least to some extent from the 'era of human rights', it remains highly doubtful as to whether the contemporary international legal system is able and willing to seriously address indigenous issues. These doubts lay at the heart of the very definition of international human rights. First, one has to be aware of the fact that human rights emerged from Western philosophy and legal thought (Paulson, 2016, p. 10; Martínez de Bringas, 2003, p. 41 ff.). Therefore, as a Western product, they follow the logic of liberal thought. This can easily be demonstrated by comparing the classic definition of international human rights to the objections on liberalism raised by indigenous peoples. Generally, universal human rights are defined as individual rights or entitlements granted by international law against a nation-state (Shaw, 2014, p. $194 \mathrm{ff}$.). This definition comprises at least three elements that contradict indigenous value systems and philosophy: Firstly, human rights are individual rights. Indigenous peoples however often conceive individualism only as exercised in their community or group, thus in the collective. Collectivism or communitarianism is essential within indigenous thought. Secondly, human rights are directed against a nation-state. However, most indigenous peoples reject the concept of the nation-state and question its legitimacy due to its colonial establishment. Thirdly, the claim of universality of human rights may be conceived as a unilateral imposition of Western-rooted values, wherefore, bearing in mind the colonial legacy of international law, it often raises suspicion and mistrust among indigenous peoples (Paulson, 2016, p. 10; Mar- 
tínez de Bringas, 2003, p. 41 ff.). Furthermore, particular rights or guarantees of human rights may lead to opposition. In this context, probably the best example is the right to private property, which is in principle diametrically opposed to indigenous models of economy (Escobar, 2010,p. 34 citing Paco, 2004, p. 171 f.; Huanacuni, 2010b).

Despite these conceptual shortcomings of international human rights theory, in practice human rights have proven more flexible and sensitive in recent years. For example, although the concept of collective rights, instead of individual rights only, remains broadly criticised particularly by liberal scholars (Wenzel, 2008, pp. 220 ff.; Jovanovic, 2012, p. 140 ff.), it nowadays seems that international law has accepted the existence of collective rights. In this sense, the IACtHR has applied a sensitive understanding of the right to property according to Art. 21 ACHR. In several cases, the court admitted that the notion of property in a purely liberal sense did not fit the various forms of property, wherefore the scope of Art. 21 AMRK was extended to collective land tenure systems of indigenous peoples (IACtHR, 2001; IACtHR, 2007; IACtHR, 2012). In Sarayaku v Ecuador, the court confirmed its findings of the decision Awas Tingni v Nicaragua by holding:

Article 21 of the American Convention protects the close relationship between indigenous peoples and their lands, and with the natural resources on their ancestral territories and the intangible elements arising from these.The indigenous peoples have a community-based tradition related to a form of communal collective land ownership; thus, land is not owned by individuals but by the group and their community. These notions of land ownership and possession do not necessarily conform to the classic concept of property, but deserve equal protection under Article 21 of the American Convention. Ignoring the specific forms of the right to the use and enjoyment of property based on the culture, practices, customs and beliefs of each people, would be tantamount to maintaining that there is only one way to use and dispose of property, which, in turn, would render protection under Article 21 of the Convention illusory for millions of people (IACtHR, 2012: § 145).

Moreover, the court determined that the right to property did not solely apply to indigenous territories as such, but comprised the surface and subsurface resources on the respective lands since it "would be meaningless for indigenous and tribal communities if that right were not connected to the protection of natural resources in the territory' (IACtHR, 2012: § 146). 
Clearly, these developments are to be highly appreciated, but nevertheless fail to comprehensively embrace indigenous criticism on human rights and international law in general: Firstly, since the notion of property has been used to dispossess indigenous peoples' lands, it appears almost cynical that they are now expected to base their claims on the right to property, the concept that has been responsible for their dispossession in the first place. Secondly, basing their lawsuits on the right to property does not change anything with regard to the internal colonisation of indigenous peoples: The nation-state, which claims sovereignty over indigenous peoples' ancestral lands, remains a colonising force by referring to the doctrine of sovereignty. Thirdly, the universality claim of human rights implies that the liberal value system is the exclusive and proper one for all people and peoples of the world. The establishment of universally applicable human rights thus led to some sort of 'legal centralism' (Griffiths, 1986, p. 2 f.) of international law. Two of the cornerstones of this 'standardisation' of law are property and sovereignty, which contradict indigenous peoples value systems. In conclusion, due to universal human rights, indigenous peoples find themselves trapped in a hegemonic liberal world, which they refuse. This raises the question as to how international law should address this double windmill.

\section{Legal Pluralism as a Method of Interpretation: A Pluralist Approach to International Law}

Regarding the resolution of conflicts arising due to the opposing convictions of liberal nation-states and indigenous peoples, two possible approaches are evident. The first approach corresponds to the immanent logic of international law, wherefore it will subsequently be referred to as the 'liberal approach'. In this sense, one could argue that international law is a fact and has historically developed in accordance with Western worldviews. Thus, historical injustices cannot simply be reversed, wherefore the contemporary system has to be accepted and justice to be sought within this Western framework. For indigenous peoples this would mean that they have to assume the language and logic of international law, and forward their claims based on human rights such as the right to property. Sovereignty, on the other hand, remains an exclusive power of the nation-state. This liberal approach however, in an age in which decolonisation is declared as one of the main 
endeavours of the UN and of international law in general ${ }^{12}$, is, due to its obviously colonial logic, simply untenable.

The second approach that is at hand will in the following be called 'restitutional approach' since it focuses on the restitution of indigenous lands and on the redemption of historical injustices. This restitutional approach thus constitutes the counterpart to the liberal approach. The underlying idea is that international law is a purely colonial concept, which has led to horrifying injustices such as major dispossession, forced relocations and genocides on a universal scale. Therefore, the concept of international law, as it stands today, has to be rejected and wholly abandoned in order to replace it with a new international legal system that is not, or at least not exclusively, based on nation-states. Liberal concepts such as the nation-state, sovereignty and property would thus have no room in such an approach. Successor states of the colonial administration would have to be considered illegitimate and illegal, acquired territories would have to be restituted and descendants of the colonisers would have no right to live within the territories of the successor states. In sum, the restitutional approach would require the re-establishment of the pre-colonial status. Regarded from a justice-based perspective, the restitutional approach seems suitable. However, two major disadvantages are obvious. Firstly, it seems very unlikely that such a fundamental conceptual shift could actually take place. In this sense, it denies the reality of the world order and proves very unpractical. Secondly, assuming that neither liberalism nor the indigenous cosmovision stand in a relation of hierarchy to each other, liberal culture has the same right of existence as indigenous cultures. By adopting a purely restitutional approach, one would run the risk of committing the same mistakes Western societies have committed, namely the unilateral imposition of a legal system, allowing only for one 'correct' worldview.

As regards conflict resolution neither the liberal approach nor the restitutional approach thus proves helpful or desirable. Therefore, the author proposes a third approach to the resolution of conflicts arising from the opposing convictions of liberalism and indigenous cosmovision, which subsequently will be referred to as the 'pluralist approach'. This pluralist approach can be described as a unifying theory, allowing for indigenous cosmovisions

12 Arts. 2(1), 73(b) Charter of the United Nations; General Assembly Resolutions 1514 (XV) of 14 December 1960; 1541 (XV) of 15 December 1960; 1654 (XVI) of 27 November 1961. 
while not denying the factual existence of international law as it operates nowadays. In this sense, it attempts to take up the insights of legal pluralists and to use their observations to interpret the liberal language of international law. In this sense, legal pluralism is employed as a method of interpretation of international law.

\section{Legal Centralism and Legal Pluralism}

Before presenting the proposed pluralist approach, some basic considerations of 'legal centralism' and 'legal pluralism' have to be made. The author's understanding of the term legal centralism refers to John Griffiths. He defines legal centralism as the 'ideology [that] law is and should be the law of the state, uniform for all persons, exclusive of all other law' (Griffiths, 1986, p. 3). Hence, other existing normative orders are hierarchically subordinate to the law of the state. However, as it is here focused on an international law perspective, one amendment has to be made: legal centralism as proposed in this context does not only focus on state law as domestic law, but also encompasses international law. ${ }^{13}$ As has been shown in the previous sections, by imposing a Western concept of international law upon indigenous cosmovision, international law and its universal pretence is considered legal centralism since it functions as an exclusionary concept of law. In this sense, it narrows the perspective of finding appropriate conflict resolutions in situations in which contradicting normative orders collide (Kuprecht, 2013, p. 20). In contrast, by legal pluralism the author refers to what Engle Merry describes as 'a situation in which two or more legal systems coexist in the same social field' (Engle Merry, 1988, p. 870 with reference to Pospisil, 1971; Griffiths, 1986; Falk Moore, 1986). For the purposes of the situation at hand, two remarks have to be made. Firstly, the term 'legal system' is broadly understood as comprising any sort of normative orders such as customs and traditions arising from their corresponding conviction, which serve as a normative basis for social behaviour. Secondly, since the situations concerned focus on the interplay between pre-colonial normative orders and the imposed colonial legal systems, legal pluralism

13 Admittedly, one could claim that "state law" encompasses international law since the latter is mainly a product of nation-states in the current state-centralised international law system. However, as international law is considered a separate legal order, this distinction seems to be reasonable. 
subsequently corresponds to what Engle Merry describes as 'classic legal pluralism' (Engle Merry, 1988, p. 872). In conclusion, the notion of legal pluralism, for the purpose of the proposed pluralist approach to international law, is defined as a situation in which both normative orders arising from indigenous cosmovisions and from liberal state or international law coexist, regulate and thus serve as a normative basis for social behaviour.

\section{The 'Pluralist Approach'}

Legal pluralism essentially expects scholars to take into account various normative orders that may have an impact or relevance on a given situation (Berman, 2009, p. 226; Engle Merry, 1988, pp. 877 f.). Furthermore, it has been argued that normative orders diverging from state law or international law, may not only define social norms, morality or ethics, they may even constitute an autonomous set of 'law' (Kuprecht, 2013, p. 21 with reference to Bermann, 2009, p. 228 f.; Teubner and Korth, 2012, p. 31). Nevertheless, the idea that normative orders not qualifying as state law may constitute law that is not necessarily subordinate to state law, says nothing about the relation to each other, possible hierarchies of the respective normative orders, or potential conflict resolution approaches in a legally pluralistic situation. This therefore raises the question as how to resolve such situations in practice. The author proposes a pluralist approach as a possible conflict resolution strategy that accepts international law as a factual reality, without resorting to colonial methods. The first assumption of this approach is that there is no hierarchy between different ideologies, convictions or philosophies. Consequently, there cannot be a hierarchy of diverging or even contradicting normative orderings. Hence, normative bases or norms guiding social behaviour stemming from different ideologies and their corresponding normative orderings are to be considered equal. In practice, this means that norms prohibiting the commodification of land, based on indigenous cosmovision, are equally legitimate as norms allowing the treatment of lands as a commodity, based on liberalism.

In the case of indigenous peoples and their ancestral lands, both norms according to their cosmovision and norms of international law are, due to the universality of international law, principally applicable. In such a situation, two cases may be at hand. Firstly, the norm derived from indigenous 
cosmovision and the norm derived from international law do not collide. In this case, there is no conflict, thus there is simply no requirement for conflict resolution. If, secondly, however the norm derived from indigenous cosmovision and the norm derived from international law are not compatible, I propose that the international law norm must be interpreted according to the indigenous cosmovision. In this sense, the existence of a norm derived from indigenous cosmovision influences, or even alters the content and meaning of the norm of international law. How this interpretation should be put into practice will be elaborated in the next section.

\section{A Pluralist Approach to 'Property' and 'Sovereignty'}

As has been shown above, international law is clearly a product of Western philosophy and legal thought. Hence, the language that describes concepts of international law is necessarily a Western language. This has been illustrated with the notions of 'property' and 'sovereignty'. Moreover, these notions are inseparably anchored in liberalism with all its presumptions such as anthropocentrism, individualism, and capitalism based on private property. Thus the concepts of 'property' and 'sovereignty' may not, or not in the same sense, exist in indigenous cosmovision. For example, the relationship of indigenous peoples to their lands differs strongly from the relationship of Western nation-states to their territories, but nevertheless, the basic concept that there exist norms regulating the relation between human beings and the territory on which they live, is common to both liberalism and indigenous cosmovisions. However, the concepts of 'property' and 'sovereignty' simply are not appropriate to describe indigenous concepts of their relationship towards the land. A pluralist approach thus needs to translate indigenous concepts into the Western language of international law. For example, when it is argued that the relationship of indigenous peoples to their lands is necessarily communitarian, an indigenous concept is translated into Western language, since communitarianism as such is a Western concept, developed by Western philosophers such as Alasdair MacIntyre, Michael Walzer, Charles Taylor, and Michael Sandel. Notwithstanding the fact that communitarianism has developed in the Western world, and does thus probably not fully embrace and correspond to the relation of indigenous peoples to their lands, it nevertheless appears to grasp its very essence wherefore it serves as 
a translation from one language to the other. As Dale Turner shows, many indigenous scholars are already engaged in the process of translating indigenous concepts into Western language (Turner, 2006, p. $189 \mathrm{ff}$.). In this sense, norms of international law must not be understood as conceptions inextricably linked to liberalism, but rather as empty vessels, or containers, which need to be filled up with content and meaning. Thus, 'property' and 'sovereignty' must be considered value free containers, which simply describe the broader relation between human beings and the territory. This intellectual game thus allows for a pluralist interpretation of international law.

With regard to 'property', the IACtHR argues that due to an 'evolutionary interpretation' (IACtHR, 2001: $\$ 148$ ) of the concept of property, indigenous peoples' collective land ownership falls under the protection of the right to property according to Art. $21 \mathrm{ACHR}$. The Court went on:

Among indigenous peoples there is a communitarian tradition regarding a communal form of collective property of the land, in the sense that ownership of the land is not centered on an individual but rather on the group and its community. Indigenous groups, by the fact of their very existence, have the right to live freely in their own territory; the close ties of indigenous people with the land must be recognized and understood as the fundamental basis of their cultures, their spiritual life, their integrity, and their economic survival. For indigenous communities, relations to the land are not merely a matter of possession and production but a material and spiritual element which they must fully enjoy, even to preserve their cultural legacy and transmit it to future generations (IACtHR, 2001: § 149).

In this sense, the Court relied on a broad notion of property, describing the relation between humans and territory. From there on, it took into account norms stemming from the indigenous cosmovision and filled the empty vessel with content. At first glance, this evolutionary interpretation appears to be related to the living instrument doctrine (ECtHR, 1978) of the European Court of Human Rights (ECtHR). While it is true, that also the living instrument doctrine 'often raises the human rights standard above what most contracting states currently offer' (Letsas, 2013, p. 12), the rationale behind the two concepts of interpretation differ. Whereas the ECtHR broadens the scope of protection due to 'common values' and 'emerging consensus' in international law (Letsas, 2013, p. 12), the IACtHR bases its evolutionary interpretation on the fact of the 'very existence' of indigenous peoples and 
their relationship to their lands which 'are not merely a matter of possession and production but a material and spiritual element' of their survival. Thus instead of the common values on which the ECtHR bases its living instrument doctrine, the IACtHR invokes distinct values for its evolutionary interpretation. In this sense, the evolutionary interpretation of the IACtHR appears to resemble the proposed pluralist approach. However, the pluralist approach goes further in the sense that it is able, at least to some extent, to limit the colonially established state. This becomes evident by looking at restrictions of human rights of the Inter-American regime. For example, Art. 21 ACHR states that '[n]o one shall be deprived of his property except upon payment of just compensation, for reasons of public utility or social interest, and in the cases and according to the forms established by law' ${ }^{14}$. Therefore, the right to property can in certain cases be restricted by the state:

$[\mathrm{P}]$ roperty rights, like many other rights recognized in the Convention, are subject to certain limitations and restrictions. In this sense, Article 21 of the Convention states that the 'law may subordinate [the] use and enjoyment of the right to property where the restrictions are: a) previously established by law; b) necessary; c) proportional, and d) with the aim of achieving a legitimate objective in a democratic society. In accordance with this Article (...) the State will be able to restrict, under certain circumstances, the Saramaka's property rights, including their rights to natural resources found on and within the territory (IACtHR, 2007: $§ 127$ ).

However, the Court was aware that such a liberal restriction amounts to continuing dispossession of indigenous peoples, as these requirements are easily met, especially under the pretension of economic growth through extraction of natural resources. However, natural resource extraction usually affects indigenous peoples in the most devastating fashions imaginable (Caruso et al., 2003, p. 3). Whether or not the Court was aware of this set of problems, it established a higher threshold for the expropriation of indigenous lands, requiring that a restriction of the right to property must not deny indigenous peoples' survival:

Furthermore, in analyzing whether restrictions on the property right of members of indigenous and tribal peoples are permissible (...) another crucial

14 Art. 21(2) ACHR, emphasis by the author. 
factor to be considered is whether the restriction amounts to a denial of their traditions and customs in a way that endangers the very survival of the group and its members. That is (...) the State may restrict the Saramakas' right to use and enjoy their traditionally owned lands and natural resources only when such restriction complies with the aforementioned requirements and, additionally, when it does not deny their survival as a tribal people (IACtHR, 2007: § 128).

In order to ensure that a restriction of the right to property does not entail a denial of their survival the state must comply with several safeguards (IACtHR, 2007: $§ 129$; IACtHR, 2012: $\$ 157)$. Inter alia, the state must 'conduct an appropriate and participatory process that guarantees the right to consultation' (IACtHR, 2012: $\S$ 157) according to the standards of Art. 6(2) ILO-Convention Nr. 169. However, the ILO-Convention 169 only requires consultation instead of consent, meaning that in any case ultimate power of disposition remains with the nation-state. Such an interpretation of indigenous land rights contravenes norms stemming from indigenous cosmovisions since land is inseparable from its inhabitants and irreplaceable with compensation in form of financial means or land substitutes. Contrary to this evolutionary interpretation a pluralist interpretation of property must take into account the inalienability of indigenous lands. With regard to the right to property two interpretations are in accordance with a pluralist approach: Firstly, the right to property in the case of indigenous land rights must be absolute; or, secondly, consent as a binding veto right instead of mere consultation must be given by the affected indigenous people.

With regard to 'sovereignty', from a perspective of international law, one has to admit that sovereignty in the sense of territorial integrity remains a sacrosanct principle of international law (Shaw, 2014, p. 153 ff.; Cassese, 2005 , p. 46 ff.). In accordance with the pluralist approach, 'sovereignty' first must be stripped down to its broader, more abstract meaning. 'Sovereignty' in a broader sense, not unlike 'property' refers to the relation between human beings and territory. However due to the pluralist approach, what sovereignty in an indigenous understanding ultimately means must be defined by indigenous peoples themselves. From an indigenous perspective it has been reiterated that 'sovereignty' refers to self-determination and self-government, as Joanne Barker, a Lenape (Delaware) scholar, puts it: 
[Sovereignty] has (...) been rearticulated to mean altogether different things by indigenous peoples. In its link to concepts of self-determination and selfgovernment, it insists on the recognition of inherent rights to the respect for political affiliations that are historical and located and for the unique cultural identities that continue to find meaning in those histories and relations (Barker, 2005, p. 26).

In the same vein, June McCue, also a scholar of indigenous descent, emphasises the nexus of sovereignty, self-determination and self-government. She describes an indigenous understanding of sovereignty as follows:

I can connect sovereignty and self-determination within the distinct context of my people by making an analogy to the trees on my Clan or house territory. The roots, trunk, and bark of the trees represent sovereignty to me. The special sap, food, medicines and seedlings that come from our trees are symbiotic with the life force or energy of my people and the land, united in a consciousness and connected through the web of life. To me, this is like self-determination or the exercise of sovereignty. The specific species of the trees represents the sovereignty and self-determination inherently and uniquely intertwined within the culture of my people. We have traditional methods to keep our trees strong, healthy, productive and secure. Like trees, we have continued to stand despite clear-cut logging and other unsustainable natural resource practices by state and industry, insect infestations, and diseases brought about through contact and climate change. (...) Indigenous conceptions of sovereignty are found in the respective traditions of Indigenous peoples and their relationships with their territories. The power to exercise sovereignty flows from their laws, customs, and governing systems and their interconnectedness with the Earth. When I use the term sovereignty, I mean the way that my people governs itself in accordance with our clan/potlatch system regardless of past, ongoing, and future colonizing state conduct (McCue, 2007, p. 24).

Taiaiake Alfred first draws attention to the artificiality of the concept of 'sovereignty', and thus arguing that the concept is open to reinterpretation. In a second step, he proposes a concept based on integrity and autonomy:

The reification of sovereignty in politics today is the result of a triumph of a particular set of ideas over others - no more natural to the world than any other man-made project. Indigenous perspectives offer alternatives, beginning with the restoration of a regime of respect. This ideal contrasts with the 
statist solution, still rooted in a classical notion of sovereignty that mandates a distributive rearrangement but with a basic maintenance of the superior posture of the state. True indigenous formulations are non-intrusive and build frameworks of respectful coexistence by acknowledging the integrity and autonomy of the various constituent elements of the relationship. They go far beyond even the most liberal Western conceptions of justice in promoting the achievement of peace, because they explicitly allow for difference while mandating the construction of sound relationships among autonomously powered elements (Alfred, 2006, p. 46).

After the said, it appears that indigenous sovereignty mainly refers to self-determination, and thus ultimately to political and territorial autonomy. ${ }^{15}$ Although international law increasingly accepts the demand for indigenous peoples' political autonomy (Gilbert, 2006, p. $226 \mathrm{ff}$.), it is often restricted and imposed by the state without consulting the concerned indigenous people as in the case of the Adivasis in India or the Kalaallit (Inuit) of Greenland (Bhengra et al., 1999, p. 29; Gilbert, 2006, p. 241 ff.). In this sense, political autonomy is granted by the nation-state due to its goodwill instead of an obligation of international law. This practice is paternalistic and cannot address indigenous claims (Gilbert, 2006, p. 241). Employing a pluralist interpretation instead of a statist interpretation of self-determination and political autonomy would mean that the extent and content of autonomy is defined by the indigenous people themselves and not by the state. Ultimately this entails an obligation of the state to accept indigenous claims of self-determination, self-government and autonomy. What self-determination, self-government and autonomy concretely mean, however, can and shall not be determined abstractly. Rather states are obliged to enter into a real dialogue on the notion of sovereignty with indigenous peoples giving them the opportunity to develop their own concepts of sovereignty, self-determination, self-government and autonomy.

\section{Conclusions}

In conclusion, nation-states and international law itself have to admit that the concept of international law stems from colonialism and is thus

15 Not only personal autonomy as proposed by as Göcke, 2016, p. 729. 
inextricably connected to the denial of indigenous rights and the dispossession of indigenous lands. Even though the renovation of international law and the adoption of universal human rights may have led to an amelioration of indigenous peoples' land rights, it must be clear that these reforms have not proven appropriate, or at least, sufficient regarding indigenous land rights, in particular with a view to the concepts of 'sovereignty' and 'property'. These concepts clearly contradict indigenous cosmovisions and the norms stemming from them and have created somewhat of a 'standardisation' or 'legal centralism' of international law, wherefore indigenous peoples find themselves trapped in a hegemonic liberal world. In order to resolve this double windmill, it is here argued that neither the exposed 'liberal approach' nor the 'restitutional approach' offer satisfying solutions. Thus as a unifying theory and conflict resolution strategy, it is proposed to employ legal pluralism as a method of interpretation. This 'pluralist approach' takes into account the various normative orders that are relevant in the case of indigenous land rights, that is to say, international law provisions and indigenous norms regulating their relation to their lands and territories. In the case of a conflict of these normative orders, it is proposed that international law is to be interpreted in accordance with indigenous cosmovisions. Hence, the notions of sovereignty and property must serve rather as value free containers than pre-defined liberal concepts. With regard to the notion of property, this ultimately means that the rights to collective property of indigenous peoples must be interpreted either as absolute rights or that any encroachment on them must be justified by consent, understood as a binding veto right, given by the affected indigenous peoples. As regards sovereignty, an indigenous interpretation mainly refers to what can be described as political and territorial autonomy defined by indigenous peoples itself, which ultimately entails an obligation of the state to respect indigenous claims of self-determination, self-government and autonomy. 


\section{Bibliography}

Monographies, books and journal articles

Alfred, T. (2006). Sovereignty. In Joanne Barker (Ed.), Sovereignty Matters: Locations of Contestation and Possibility in Indigenous Struggles for SelfDetermination. Lincoln: University of Nebraska Press.

(2009). Peace, Power, Righteousness: An Indigenous Manifesto. Oxford: University Press.

Altmann, Ph. (2016). Buen Vivir como propuesta politica integral: Dimensiones del Sumak Kawsay. Revista Latinoamericana de Política y Acción Pública, 3(1), 55-74.

Anaya, J. S. (2002). The Contours of Self-Determination and its Implementation: Implications of Developments Concerning Indigenous Peoples. In Gudmunder Alfredsson, y Maria Stravropoulou, (Eds.), Justice Pending: Indigenous Peoples and Other Good Causes - Essays in Honour of EricaIrene Daes. The Hague and New York: Martinus Nijhoff.

(2004). Indigenous Peoples in International Law. Oxford: University Press.

(2009). International Human Rights and Indigenous Peoples. New York: Wolters Kluwer Law \& Business.

Aristotle (2004). Politics. In HenryFielding, Benjamin Jowett (Eds.), Politics. Coral Springs: Nuvision Publications.

(2014). Nicomachean Ethics. In Henry Fielding, Roger Crisp (Ed.), Nicomachean Ethics. Cambridge: University Press.

Baer, L. A. (2000). The right of self-determination and the case of the Sami. In Pekka Aikio, y Martin Scheinin (Eds.), Operationalizing the right of indigenous peoples to self-determination. Turku/Åbo: Institute for Human Rights, Åbo University.

Barker, J. (2005). For Whom Sovereignty Matters. In Joanne Barker (Ed.), Sovereignty Matters: Locations of Contestation and Possibility in Indigenous Struggles for Self-Determination. Lincoln: University of Nebraska Press.

Bhengra, R., et al. (1999). The Adivasis of India, Minority Rights Group International Report, 1998.

http://citeseerx.ist.psu.edu/viewdoc/download?doi=10.1.1.432.8615\&rep=rep1\&t ype=pdf $>$ [January 11, 2017]. 
Berman, P. Sch. (2009). The New Legal Pluralism. Annual Review of Law and Social Science, 5, 225-242.

Bodin, J. (1576/1606). Six Books of the Commonwealth. In Richard Knolles (Ed.), Six Books of a Commonweale. London: Implensis G. Bishop.

Caruso, E. et al. (2003). Extracting Promises: Indigenous Peoples, Extractive Industries and the World Bank. Moreton-in-March: Forest Peoples Programme.

Cassese, A. (2005). International Law. $2^{\text {nd }}$ ed. Oxford: University Press.

Churchill, W. and Morris, G. T. (1992). Key Indian Laws and Cases. In M. Annette Jaimes (Ed.), The State of Native America: Genocide, Colonization, and Resistance. Boston: South End Press.

Chief J. M. and Yabsley, G. R. (1991). Conspiracy of Legislation: The Suppression of Indian Rights in Canada. BC Studies, 89, 34-47.

Conn, S. (1988). Inside Brazilian Indian Law: A Comparative Perspective. In Bradford Morse, and Gordon Woodman (Eds.), Indigenous Law and the State. Dordrecht: Foris Publications.

Corntassel, J. and Hopkins Primeau, T. (1995). Indigenous, 'Sovereignty' and International Law: Revised Strategies for Pursuing, 'Self-Determination'. Human Rights Quarterly, 17(2), 343-365.

Cortez, D. (2010). Genealogía del 'buen vivir' en la nueva constitución ecuatoriana. Studien zur Befreung und Interkulturalität, 30, 227-248.

(2011). La construcción social del 'Buen Vivir' (Sumak Kawsay) en Ecuador. Genealogía del diseño y gestión política de la vida. Aportes Andinos, 28, 1-23.

Cortez, D. and Wagner, H. (2010). Zur Genealogie des indigenen "guten Lebens" ("Sumak Kawsay") in Ecuador. In Leo Gabriel, and Herbert Berger (Ed.), Lateinamerikas Demokratien im Umbruch. Wien: Mandelbaum Verlag.

Davenport, F. G. (1917). European Treaties bearing on the History of the United States and its Dependencies to 1648. Washington, D.C.: Carnegie Institute of Washington.

Davidson, S. (1994). The Rights of Indigenous Peoples in Early International Law. Canterbury Law Review, 5(3), 391-423.

Doyle, C. M. (2015). Indigenous Peoples, Title to Territory, Rights and Resources: The transformative role of free prior informed consent. London and New York: Routledge.

Engle Merry, S. (1988). Legal Pluralism. Law \& Society Review, 22(5), 869-896. Escobar, A. (2010). Latin America at a Crossroads. Cultural Studies, 24(1), 1-65. 
Falk Moore, S. (1986). Social Facts and Fabrications: Customary Law on Kilimanjaro, 1880-1980. Cambridge: University Press.

Flanagan, Th. (1989). The Agricultural Argument and Original Appropriation: Indian Lands and Political Philosophy. Canadian Journal of Political Science, 22(3), 589-602.

Gilbert, J. (2006). Indigenous Peoples'Land Rights Under International Law: From Victims to Actors. New York: Transnational Publishers.

Gilbert, J. and Doyle, C. M. (2011). A New Dawn Over the Land: Shedding Light on Collective Ownership and Consent. In Stephen Allen, and Alexandra Xanthaki, (Eds.), Reflexions on the UN Declaration on the Rights of Indigenous Peoples. Oxford and Portland, Oregon: Hart Publishing.

Göcke, K. (2016). Indigene Landrechte im internationalen Vergleich. Heidelberg: Springer.

Griffiths, J. (1986). What is Legal Pluralism? Journal of Legal Pluralism, 24, pp. 1-55. Hidalgo-Capitán, A. L. (2012). El Buen Vivir ecuatoriano en el contexto de la Economía Política del Desarrollo. In Rafael Domínguez, y Sergio Tezanos (Eds.), Actas del I Congreso Internacional de Estudios del Desarrollo. Santander: Universidad de Cantabria.

Hidalgo-Capitán, A. L. and Cubillo-Guevara, A. P. (2013). Seis debates abiertos sobre el sumak kawsay. Iconos Revista de Ciencias Sociales, 48, pp. 25-48.

Hinsley, F. H. (1966). Sovereignty. Cambridge: University Press.

Hobbes, Th. (1691). Leviathan or The Matter, Forme, \& Power of a Commonwealth Ecclesiasticall and Civill. London: Green Dragon.

Houtart, F. (2011). El concepto de Sumak Kausay (Buen vivir) y su correspondencia con el bien común de la humanidad. Revista Ecuador Debate, 84, pp. 57-76.

Huanacuni, F. (2010a). Buen Vivir/Vivir Bien. Filosofía, políticas, estrategias y experiencias regionales andinas. Lima: CAOI.

(2010b). Paradigma occidental y paradigma indígena originario. América Latina en movimiento, 452, 17-22.

Joseph, B. (2012). "Potlatch Ban: Abolishment of First Nations Ceremonies." 〈http://www.ictinc.ca/the-potlatch-ban-abolishment-of-first-nations-ceremonies> [January 11, 2017].

Jovanovic, M.A. (2012). Collective Rights: A Legal Theory. Cambridge: University Press.

Keal, P. (2008). Indigenous Sovereignty. In Trudy Jacobsen et al.(Eds.), Re-envisioning sovereignty: the end of Westphalia? Aldershot: Ashgate Publishing Ltd. 
Koller, P. (1981). Zur Kritik der libertären Eigentumskonzeption am Beispiel der Theorie von Robert Nozick. Analyse \& Recht, 3(2), pp. 139-154.

Kuprecht, Karolina, (2013). Indigenous Peoples' Cultural Property Claims: Repatriation and Beyond. Switzerland: Springer.

Letsas, G. (2013). The ECHR as a living instrument: Its meaning and legitimacy. In Andreas Follesdal et al. (eds.), Constituting Europe: The European Court of Human Rights in a National, European and Global Context. Cambridge: University Press.

Locke, J. (1689/2012). The Second Treatise of Government, in Mayer-Tasch, Peter Cornelius (ed.), The Second Treatise of Government. Stuttgart: Reclam.

Macas, L. (2010). Sumak Kawsay. La vida en plenitud. In Antonio Luis HidalgoCapitán, et al. (Eds.), Sumak Kawsay Yuyay. Antología del Pensamiento Indigenista Ecuatoriano sobre Sumak Kawsay. Huelva and Cuenca: FIUCUHU.

Martínez de Bringas, A. (2003). Los pueblos indígenas y el discurso de los derechos. Cuadernos Deusto de Derechos Humanos, 24, pp. 41-52.

McCue, J. (2007). New Modalities of Sovereignty: An Indigenous Perspective. Intercultural Human Rights Law Review, 2, 19-30.

Moore, J. B. (1913). Costa Rica-Panama Arbitration: Memorandum on Uti Possidetis. Rosslyn: The Commonwealth Co. Printers.

Nozick, R. (1974). Anarchy, State, and Utopia. New York: Basic Books.

Oppenheim, L. (1905). International Law: A Treatise. New York und Bombay: Longmans, Green, and Co.

Paco, F. P. (2004). Sistema comunal. Una propuesta alternativa al sistema liberal. La Paz: CEA.

Paulson, L. (2016). Los derechos humanos en un contexto local: La relación entre los derechos humanos y los movimientos Mapuche. Independent Study Project (ISP) Collection, No. 2384. 〈http://digitalcollections.sit.edu/ cgi/viewcontent.cgi?article=3409\&context=isp_collection $>$ [January 11, 2017].

Peters, A. (2016). Völkerrecht: Allgemeiner Teil. Zürich: Schulthess.

Pipes, R. (1999). Property and Freedom. New York: Alfred. A. Knopf.

Pospisil, L. (1971). The Anthropology of Law: A Comparative Theory of Law. New York: Harper and Row.

Ratner, S. R. (1996). Drawing a Better Line: Uti Possidetis and the Borders of New States. The American Journal of International Law, 90(4), 590-624. 
Rawls, J. (1971). A Theory of Justice . Cambridge: Bellknap Press of Harvard University Press.

Reisman, M. W. (1995). Protecting Indigenous Rights in International Adjudication. The American Journal of International Law, 89, 351-362.

Schmid,E. (2013). Betrachtungen zum guten Leben. Ein Vergleich zwischen dem Fähigkeitenansatz von Amarty Sen und dem Leitprinzip der ecuadorianischen Verfassung, Sumak Kawsay. «http:/momentumkongress.org/cms/uploads/ documents/Paper_Schmid21_2_2013_1118.pdf>[January 11,2017] (2014). Die Frage nach dem guten Leben. Buen Vivir in Ecuador und Entwicklung als Freiheit im kritischen Vergleich. Bremen: Wiener Verlag für Sozialforschung.

Schulte-Tenckhoff, I. (1998). Reassessing the Paradigm of Domestication: The Problematic of Indigenous Treaties. Review of Constitutional Studies, IV(2), 239-289.

Shaw, M. N. (2014). International Law. $7^{\text {th }}$ edn. Cambridge: University Press.

St. Thomas Aquinas (1265-1274/1989). Summa Theologiae, in McDermott, Timothy (ed.), Summa Theologiae. London: Eyre and Spottiswoode.

Stavenhagen, R. (2006). Los derechos de los pueblos indígenas: esperanzas, logros y reclamos. In Mikel Berraondo (Ed.), Pueblos indígenas y derechos humanos. Bilbao: Deusto.

Teubner, G. and Korth, P. (2012). Two Kinds of Legal Pluralism: Collision of Transnational Regimes in the Double Fragmentation of World Society. In Margaret A. Young (Ed.), Regime Interaction in International Law: Facing Fragmentation. Cambridge: University Press.

Thornberry, P. (2002). Indigenous Peoples and Human Rights. Manchester: University Press.

Torres Santana, A. (2012). Las voces de la tempestad: Crítica y actualidad del calibanismo. Crítica y Emancipación, IV(7), 177- 203.

Tully, J. (2007). The Struggle of Indigenous Peoples for and of Freedom. In Duncan Ivison et al. (Eds.), Political Theory and the Rights of Indigenous Peoples. Cambridge: University Press.

Turner, D. (2001). Visions: Towards an Understanding of Aboriginal Sovereignty. In Beiner, Ronald and W. J. Normann (Eds.), Canadian Political Philosophy: Contemporary Reflections. Oxford: University Press. (2006). This Is Not a Peace Pipe: Towards a Critical Indigenous Philosophy. Toronto: University Press. 
Vattel, E. de (1758/1844). The Law of Nations, Or, Principles of the Law of Nature, Applied to the Conduct and Affairs of Nations and Sovereigns. $6^{\text {th }}$ edn. Philadelphia: T. \& J.W. Johnson.

Villalba, U. (2013). Buen Vivir vs Development: a paradigm shift in the andes? Third World Quarterly, 34(8), 1427-1442.

Vitoria, F. de (1532/1917). De indis et de ivre belli relectiones. In James B. Scott, and Ernest Nys (Eds.), The Classics of International Law. Washington, DC: Carnegie Institute of Washington.

Wenzel, N. (2008). Das Spannungsverhältnis zwischen Gruppenschutz und Individualschutz im Völkerrecht. Berlin: Springer.

Westlake, J. (1894). Chapters on the Principles of International Law. Cambridge: University Press.

Williams, R. A. (1990). The American Indian in Western Legal Thought: The Discourses of Conquest. New York: Oxford University Press.

(1991). Columbus Legacy: Law as an Instrument of Racial Discrimination against Indigenous Peoples' Rights of Self-Determination. Arizona Journal of International and Comparative Law, 8(2), 1991, 51-74.

Wilmer, F. (1993). The Indigenous Voice in World Politics. Thousend Oaks: SAGE Publications.

\section{Jurisprudence}

U.S. (1823). U.S. Supreme Court, Johnson v. M'Intosh, 21 U.S. 543 (1823).

U.S. (1831). U.S. Supreme Court, Cherokee Nation v. Georgia, 30 U.S. 1 (1831).

ECtHR (1978). European Court of Human Rights, Tyrer v. United Kingdom, Merits, App. No. 5856/72, A/26, [1978], April 25, 1978.

ICJ (1992). International Court of Justice, Case concerning the land, island and maritime frontier dispute (El Salvador/Honduras: Nicaragua intervening) of $11^{\text {th }}$ September 1992, GL No. 75 [1992] ICJ Rep 351.

IACtHR (2001), Inter-American Court of Human Rights, Case of the Mayagna (Sumo) Awas Tingni Community v. Nicaragua, August 31, 2001, Series C, No. 79.

IACtHR (2006a). Inter-American Court of Human Rights, Case of the Indigenous Community Yakye Axa v. Paraguay, February 6, 2006, Series C, No. 142. IACtHR (2006b). Inter-American Court of Human Rights, Case of the Sawhoyamaxa Indigenous Community v. Paraguay, March 29, 2006, Series C, No. 146. IACtHR (2007). Inter-American Court of Human Rights, Case of the Saramaka People v. Suriname, November 28, 2007, Series C, No. 172. 
IACtHR (2012). Inter-American Court of Human Rights, Case of Kichwa Indigenous People of Sarayaku v. Ecuador, June 27, 2012, Series C, No. 245.

Fecha de recepción: 20/0I/2017; fecha de aceptación: 30/05/2017;

fecha de publicación: 30/06/2017 